Short paper

\title{
Development of synbiotic beverage from beetroot juice using beneficial probiotic Lactobacillus Casei 431
}

\author{
S.M. Gamage ${ }^{1}$, M.K.S. Mihirani ${ }^{1}$, O.D.A.N. Perera ${ }^{1}$ and H.L.D. Weerahewa ${ }^{2}$ \\ ${ }^{1}$ Department of Food Science and Technology, Faculty of Livestock, Fisheries and \\ Nutrition, Wayamba University of Sri Lanka, Makandura, Gonawila (NWP), Sri \\ Lanka, \\ ${ }^{2}$ Department of Botany, The Open University, Nawala, Nugegoda, Sri Lanka
}

Correpondence:weerahewa@gmail.com

Received: $11^{\text {th }}$ June 2016, Revised: $24^{\text {th }}$ August 2016, Accepted: $10^{\text {th }}$ October 2016

\begin{abstract}
A beetroot beverage with Lactobacillus casei 431 as the probiotic microorganism was tested for sensory acceptability at 3 fermentation periods of 2,4 and 6 hours at $37^{\circ} \mathrm{C}$. The beverage fermented for 2 hours yielded the highest overall sensory acceptability. L. casei 431 grew well and reached nearly $10^{8} \mathrm{CFU} / \mathrm{mL}$ after 2 hours of fermentation at $37^{\circ} \mathrm{C}$. Although the lactic culture in the fermented beetroot beverage gradually lost its viability during cold storage, viable cell count of lactic acid bacteria remained at $10^{6}-10^{8} \mathrm{CFU} / \mathrm{mL}$ after 4 weeks of cold storage at $4^{\circ} \mathrm{C}$. Titratable acidity increased significantly from $5.5 \pm 0.05$ to $3.45 \times 10^{8}(P \leq 0.05)$ during storage. This study concludes that this beetroot-based synbiotic fermented beverage could be developed as a ready-to-drink product and kept for 6 weeks under refrigerated storage, meeting the standard $10^{8}-10^{10} \mathrm{CFU} / \mathrm{mL}$ of a functional drink.
\end{abstract}

Keywords. Functional food; Lactobacillus casei; prebiotics; probiotics; synbiotic beverage.

\section{Introduction}

Interest in functional foods has recently increased among consumers due to an increasing consciousness towards health and nutrition, as well as the need to prevent rather than cure diseases and also the increasing scientific evidence of their effectiveness. The concept of functional foods originated in Japan and are defined as being similar in appearance to conventional foods and used as 
part of a normal diet, but demonstrating nutritional functions beyond those considered basic, physiological benefits or reducing the chronic risk of disease: these are known as 'Food for Specified Health Use' (Hasler, 1998). Hence, food products containing probiotics and prebiotics are considered as functional food. Much research has focused on evaluating the addition of probiotics and prebiotics to obtain synbiotic food with improved final quality.

Prebiotic oligosaccharides are Non-Digestible Oligosaccharides (NDO) and low calorific compounds stimulating the growth and development of gastro-intestinal microflora described as probiotic bacteria. Dietary carbohydrates that show prebiotic ability include fructansfructooligosaccharides (FOS) and inulin, galactooligosaccharides (GOS), polydextrose, resistant starch, soyoligosaccharides, xylooligosaccharides, isomaltooligosaccharides, and lactulose (Patel and Goyal, 2012).

Probiotics are defined as selected, viable microbial dietary supplements that, when introduced in sufficient quantities, beneficially affect human organism through their effects in the intestinal tract. Some selected strains of Lactobacillus, Bifidobacterium, Streptococcus, Lactococcus and Saccharomyces have been promoted in food products because of their reputed health benefits (Sharma et al., 2012).Various researchers have discovered the use of different fruits, vegetables and cereals for producing synbiotic beverages in different countries of the world (Manzon et al., 2012; Gokavi et al., 2005).

The beetroot (Beta vulgaris), apart from consumption in its fresh form, is also a valuable vegetable used in the food industry to produce dried and frozen food, non-concentrated and concentrated juices as well as natural colorants (betalains) which are used as additives in food manufacturing. In many countries there is a growing interest in foods preserved in natural ways. Lactic fermentation is one of the methods of natural preservation and thus production of foods with the highest nutritive value. Based on the above information the present study was aimed to evaluate the production of a synbiotic beverage using beetroot juice fermented by Lactobacillus casei.

\section{Materials and Methods}

This research was carried out in the Food Processing Laboratory of the Department of Food Science and Technology, Wayamba University of Sri Lanka. Beetroot variety 'Crimson Globe' and other ingredients were purchased from a local store at Pannala. After being washed, the beetroots were peeled and cut in to small cubes with an approximate thickness of 0.5 $\mathrm{cm}$. The juice was prepared using a juice extractor (PANASONIC 800W- 
Osaka, Japan). Coarse particle content was separated gravimetrically by centrifuging beetroot juice at $1500 \mathrm{x}$ g (model 2-16 K-Braunschweig, Germany) for 20 minutes. Juice was electrically heated at a moderate temperature of $50^{\circ} \mathrm{C}$ and grounded sucrose $(40 \mathrm{~g} / \mathrm{L})$ was added. Beetroot beverage was pasteurized at $90^{\circ} \mathrm{C}$ for 1 minute. At $43^{\circ} \mathrm{C}$, a commercial frozen probiotic culture, L. casei 431 (CHR-HANSON - Denmark) (0.1g/L) was added. The beetroot beverage was allowed to ferment in a thermostat (Hengzi $\mathrm{HH}-\mathrm{B} 11.600-\mathrm{S}-\mathrm{II}$, Shanghai, China) at $37^{\circ} \mathrm{C}$ for $0,2,4$ and 6 hours.

$\mathrm{pH}$ of the beverage samples was measured using a $\mathrm{pH}$ meter (OHAUS Starter 300 Portable- Parsippany, USA). Titratable acidity was determined by titrating $10 \mathrm{~mL}$ of sample against $1.0 \mathrm{~N} \mathrm{NaOH}$ in the presence of Phenolphthalein as an indicator (Sharma, 2006). The total soluble solid content was measured by using a refractometer (ATAGO- Tokyo, Japan). Determination of moisture content, ash, protein, fat, total fiber, total sugars, reducing sugars and $\%$ sucrose was performed according to A.O.A.C. (2000).

Sensory evaluation was conducted using 31 semi-trained panelists who were requested to made a score on colour, consistency, taste, odor, and overall acceptability on a 5 point hedonic scales $(1=$ dislike extremely, $5=$ like extremely).

Viable cell counts $(\mathrm{CFU} / \mathrm{mL})$ of the inoculum were determined by the standard plate method with MRS Agar (Merck Millipore- Massachusetts, USA) medium after 48 hours of incubation at $30^{\circ} \mathrm{C}$.Coliform counts were estimated using Mac Conkey Agar (Merck Millipore- Massachusetts, USA) plates incubated at $37^{\circ} \mathrm{C}$. Yeast and mold were enumerated by a surface spread plate technique using Potato Dextrose Agar (HiMedia- Maharashtra, India) plates in triplicate. Samples were taken at weekly intervals to examine the effect of cold storage on probiotic cell viability in the beet juice.

Significant differences among treatments were analysed using ANOVA with the help of the SAS software version 9.4. Results were expressed as mean \pm SD. Non-parametric tests (5 point hedonic scale, Kruskal Wallis Test) were performed to determine the statistical difference of the sensory data, where appropriate. Differences at $P<0.05$ was considered statistically significant for all analyses.

\section{Results and Discussion}

The present study was carried out to investigate the ability of L.casei to survive in beetroot juice throughout the refrigerated storage of 6 weeks. The Lactobacillus bacteria used in this study (L. casei 431) is a novel bacterial 
strain developed by Chr.Hansen, Denmark. The initial $\mathrm{pH}$ of the beetroot juice was 5.6, a closer value to the optimum $\mathrm{pH}$ for the $L$. casei 431 strain (Paraschiv et al., 2011). However, in this study L. casei 431 reduced the $\mathrm{pH}$ of beet juice from an initial value of 5.6 to lower than 5.2 while increasing titratable acidity after a 2 hour of fermentation due to their ability to produce lactic acid prominently. In the fermentation process the rate of $\mathrm{pH}$ decrease is very important. The resultant low $\mathrm{pH}$ minimizes the influence of spoilage bacteria, particularly at the beginning of the fermentation when the substrate is rich in sugars. Table 1 illustrates the changes in $\mathrm{pH}$, titratable acidity and viable count of $L$. casei 431 after 2, 4 and 6 hour fermentation periods.

Table 1: Changes in $\mathrm{pH}$, titratable acidity, and viability of L. casei 431 in Beet root juice at different time intervals (mean $\pm \mathrm{SD})$.

\begin{tabular}{cccc}
\hline $\begin{array}{c}\text { Time } \\
(\mathrm{h})\end{array}$ & $\mathrm{pH}$ & $\begin{array}{c}\text { Titratable } \\
\text { acidity }(\%)\end{array}$ & CFU/mL \\
\hline 0 & $5.5 \pm 0.05^{\mathrm{a}}$ & $0.16 \pm 0.06^{\mathrm{a}}$ & $2.45 \times 10^{7}$ \\
2 & $5.2 \pm 0.04^{\mathrm{a}}$ & $0.19 \pm 0.11^{\mathrm{a}}$ & $2.50 \times 10^{8}$ \\
4 & $5.0 \pm 0.02^{\mathrm{a}}$ & $0.22 \pm 0.04^{\mathrm{a}}$ & $3.05 \times 10^{8}$ \\
6 & $4.9 \pm 0.01^{\mathrm{a}}$ & $0.23 \pm 0.23^{\mathrm{b}}$ & $3.45 \times 10^{8}$ \\
\hline
\end{tabular}

The means with different superscripts in a column differ significantly $(P \leq 0.05)$.

International standards stipulate that probiotic products should contain a minimum of $10^{8}$ viable probiotic bacteria per $\mathrm{mL}$ of the product at time of consumption for health and functional claims (Samona and Robinson, 1991).However, in this study, fermented beetroot juice has reached around $10^{8}$ viable probiotic bacteria per $\mathrm{mL}$ at the end of the $6^{\text {th }}$ week. Nighswonger et al. (1996) revealed that there was a slight fermentative activity by the probiotic organism even at $4^{\circ} \mathrm{C}$. Although the lactic acid cultures in the fermented beet juice gradually reduced their cell viability during refrigerated storage $\left(4^{\circ} \mathrm{C}\right)$, the viable cell counts of the lactic acid bacteria in the fermented beet juice still remained at $10^{6}-10^{8} \mathrm{CFU} / \mathrm{mL}$ (average of $10^{7} \mathrm{CFU} / \mathrm{mL}$ ) after 4 weeks of storage at $4^{\circ} \mathrm{C}$.

Some studies have revealed that several factors such as inoculum level, incubation temperature, inhibitors, and presence of hydrogen peroxide and oxygen concentration of metabolites, buffering capacity of the media, storage temperature and availability of nutrients may affect the survival of lactic acid bacterial strain (Hayek and Ibrahim, 2013). In this study, even after 6 weeks of storage at $4^{\circ} \mathrm{C}, L$. case $i$ was capable of surviving in the fermented beetroot juice at low $\mathrm{pH}$. This $\mathrm{pH}$ value can still be adequate to positively affect host health. This effect was previously demonstrated for other Lactobacillus bacterial strains for which survival under analogous conditions was enhanced 
by presence of carbohydrate present in the vegetable products (Yoon et al., 2005).

Sensory evaluation results show that beetroot juice fermented for 2 hours gives the highest ranks for colour, taste, odor, consistency and overall acceptability. Mainly, the colour of this synbiotic beetroot beverage gained higher consumer acceptance. There was an unappealing odour in the beetroot juice after 6 weeks of storage in the refrigerator.

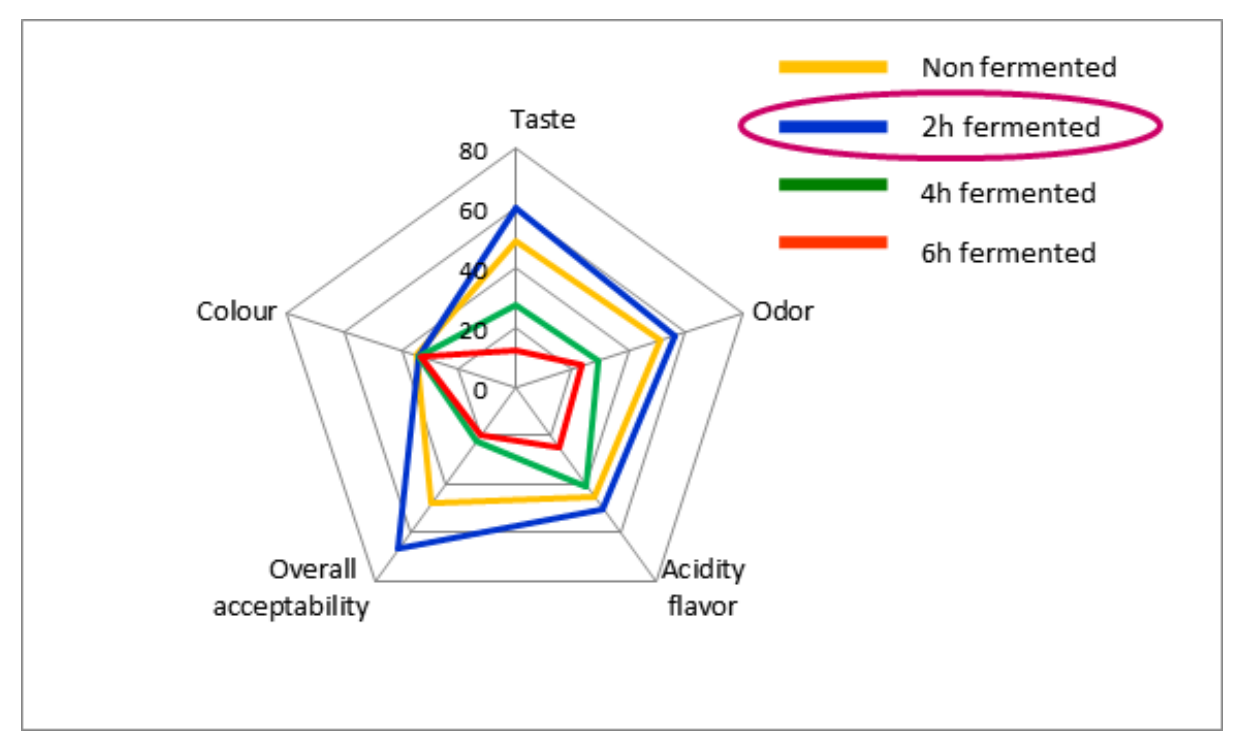

Fig 1. Mean scores for Kruskal Wallis Test at different times of fermentation

The amount of reducing sugar, sucrose and total sugars were significantly reduced $(P \leq 0.05)$ during storage and the least reduction was observed after 6 weeks of storage. Sugar consumption of $L$. casei is correlated with the lactic acid accumulation in the beverage. Therefore, sucrose addition is desirable for the purpose of maintaining of native prebiotics in the beverage. The Brix value of the beverage has slightly decreased from 5 to 4 with storage period. The reduction of total sugar content due to the fermentation process of $L$. casei is the main reason for reduction of Brix during storage.

Beetroot contains both insoluble and soluble fiber components in a desirable ratio. Mainly insoluble fibers can be considered as the prebiotics. $L$. casei is a probiotic which can metabolize above prebiotics and can live by using those prebiotics as substrates. To be a synbiotic beverage, the amount of prebiotics should be maintained until point of consumption as there are no external prebiotics introduced to the product. Therefore, the addition of 
sucrose to the beetroot beverage appeared to help retain the viability of the desired prebiotics in the final product. According to data, there was no significant reduction $(P<0.05)$ in the fiber content during the storage period. It is evident that prebiotics in the beverage have been preserved until the end of shelf life.

\section{Conclusion}

Based on the results of the present study, it can be concluded that beetroot could serve as a raw material for the production of probiotic beet juice through lactic acid fermentation with $L$. casei. The fermented beet juice has a $\mathrm{pH}$ value less than 5.5 (high acid) and contains a significant number of beneficial lactic acid bacteria $\left(10^{8} \mathrm{CFU} / \mathrm{mL}\right)$. Synbiotic beetroot beverage also showed sensory characteristics acceptable to health-conscious consumers.

\section{References}

A.O.A.C. 2000. Official method 920.1839 (b) Sugars (Reducing) in Honey, $17^{\text {th }}$ Ed, Washington DC.

A.O.A.C. 1999. AOAC Official Methods of Analysis, 14th Ed., Vol. 1, Association of Official Agricultural Chemists, Washington, DC.

Marla SJM, Daniela CUC, Nadiége DP, Mariana NR, Elizeu AR. 2012. Development of a Synbiotic Low-Calorie Beverage Made from Soy and Yacon Extracts. Food and Nutrition Sciences 3: 1500-1508.

Daniela P, Aida V, Madalina C, Alexandru C, Gabriela B. 2011. Study of physiological properties of some probiotics in multiple cultures with mesophilic lactic acid bacteria by flora danicach. Hansen commercial starter. Food Technology 35 (2): 56-65

Nighswonger BD, Brashears MM, Gilliland, SE. 1996. Viability of Lactobacillus acidophilus and Lactobacillus casei in fermented milk products during refrigerated storage. Journal of Dairy Science 79 (2): 212-219.

Saeed AH, Salam AI. 2013. Current Limitations and Challenges with Lactic Acid Bacteria: A Review. Food and Nutrition Sciences 4: 73-87.

Samona A, Robinson RK. 1991. Enumeration of bifidobacteria in dairy products. International Journal of Dairy Technology 44 (3): 64-66.

Seema P, Arun G. 2012.The current trends and future perspectives of prebiotics research: a review. Biotechnology 2 (2): 115-125.

Sheel S, Nidhi A, Preeti V. 2012. Probiotics: The Emissaries of Health from Microbial World. Journal of Applied Pharmaceutical Science 02 (1): 138-143.

Sumangala G, Lanwei Z, Ming-Kuei H, Xin Z, Mingruo G. 2005. Oat-based Symbiotic Beverage Fermented by Lactobacillus plantarum, Lactobacillus paracasei ssp. casei, and Lactobacillus acidophilus. Journal of Food Science 70 (4): 216-223.

Yoon YK, Woodams EE, Hang YD. 2005. Fermentation of beet juice by beneficial Lactic acid bacteria. Lebensm Wiss Technol 38: 73-75. 